\title{
EFFECT OF GENDER AND AGE AND DATE OF COLLECTION ON SOME SPECIFICATIONS OF GUM EXCRETED FROM PISTACIA VERAL. TREES IN MOSUL
}

\author{
Abdullah, A. S. Rajab Agha, A. A. H. \\ Forestry dept. College of Agric. \& forestry. Mosul/ Iraq \\ E-mail: ahmadalhialy@yahoo.com
}

\begin{abstract}
The current study included the effect of gender, age and date of collection on the Pistacia vera gum growing in the Nineveh province. The study included the effect of gender (female, male), three ages $(16,23,35)$ and the date of collection included three dates (July, August and September). Gum collected from each trees, the chemical fractionation of the gum was carried out as essential oils and polymer, also acid group types (A, B, C). The results showed the significant effect of the species of the tree, age and date of collection on the amount of gum, where the moral superiority of the gender of the male $(23.06 \mathrm{~g})$ on the female gender $(19.34 \mathrm{~g})$ and the increase in the quantity with age to $28.95 \mathrm{~g}$. At the age of 35 years, August was the best time for collection $(25.0 \mathrm{~g})$. Significant effects of age and date of collection were found on the percentage of essential oils, the highest percentage was at 16 years (15.8) and the percentage of essential oils in July and August were (15.2 and 15.1). The results showed the high significant effect of the age and the time of collection on the polymer ratio. The highest ratio $51.99 \%$ was at the age of 35 years and $49.71 \%$ for September. The proportion of polymer in the gender of the male was $(49.47 \%)$.
\end{abstract}

Key words: Pistacia vera, gum, yield, essential oil, polymer

Received: 6/11/2018, Accepted: 10/10/2019

\section{INTRODUCTION}

Pistacia vera trees and shrubs of the (Anacardiaceae) which belong to Sapindales and includes (79) kinds, and about (600) kinds are characterized by desert trees grow to (8-10 meters) and these trees and shrubs excrete gum and they are distributed in the Mediterranean countries to Central Asia (Bozorgiet al., 2013). These kinds which belong to (Anacardiaceae) produce the same quality of resin gum (Bailey, 1963), which have the same features compared with Chios island sample with respect to resin gum (Boztok and Zeybek, 2004) which is called mastic gum.

The excreted gum from these trees is produced naturally from the bark and it is obtained by making longitudinal incisions in the bark to make the gum in the form of liquid which is known (Chios tears) due to mastic origin which is found in Greek Chios island, where it is dried by sun to become solid or semi- solid pieces, crispy and look like pear or globular granules with a diameter of $(4-8 \mathrm{~mm})$ with pale yellow color then become faded and crispy with aromatic smell and acceptable taste (Bozorgi et al., 2013)

Trees gum is a natural product and a chemical formation having medicinal features which are varied by the different of source, it may not be stable depends on 
many climatic factors, soil factors, season and tree's age which collects gum (Ali et al., 2013). Mosutaki is defined by IbnSina and he referred to the possibility of treating many diseases by Mosutaki . Mosutaki is also defined by Ibn Al-Bayttar, he called it Mosutaki gum and referred to treating the higher part of abdomen (AlShahaat, 1998). Ibn Al-Baytaar called Pistacia vera gum with Anbat gum and described it that it has a white color produces from Pistacia tree so they wound the tree in many positions so it flows from these wounds, they collect and dry it by sun and it has a bitter taste (Ibn Al-Baytaar, 2001).

Mastic has been used to treat many numbers of diseases even the malignant diseases, where it has been used for many centuries as a nutritive supplement in human medicine and treating gastric ulcers, duodenum in many countries which are overtopping on Mediterranean (Min et al., 2009). Studies showed some medicinal effects such as dropping hypertension and pains in the higher part of the abdomen, gastric pains, indigestion and gastric ulcers (Yousefi, 2016). Also mastic gum and essential oils extracted from pistachios are considered natural antimicrobials which have wide usages in Mediterranean countries and the middle east since ancient eras (Gallis et al., 2011). Concerning recently mastic gum usages, they have been expanded more and more where they were used in making sorting fibers used in surgery for being absorbed by the human body and also used as a sterilization for mouth and stretching for gums (Al-Mofraji et al., 2013). This gum is considered as an anti-cancer factor especially against malicious breast tumors, gastric tumors, liver, spleen and womb, and this is agreed with the last studies which show that mastic gum disables the activity and growing of colon cancer cells (Balan et al., 2007).

Three crystalline components (Masticedienonic, Isomasticedienonic and Oleanouic) and one component of equal part of mastic gum Tirucallol by (Barton and Seoane 1956) were isolated and diagnosed. In 1973 six asters of acid were isolated by Chrome Tokra, also eight terpenes were isolated, three of them from the equal part (Monaco et al., 1973). As well as, many studies were conducted on the chemical composition of essential oils for P. lentiscus and the main components were monoterpene (Papageorgiouet al., 1991), and in 1998 Van Den Berg et al. diagnosed a non-normal polymer and it was the first discovery of a natural monoterpene with a molecular weight reaches to 100000 (Cis - 1,4 - poly - B myrcene).

The gum production from the male Pistacia Lentiscus was more than the female gum, so we only can take mastic gum from the male trees for being more productivity than the female ones (Isfendiuaroglu, 2003), also male trees produce tough resin greater then resin produced in the female trees.

The yield of essential oils obtained from mastic gum was (w.w5.20\%) and it is found that the polymeric part had a molecular weight 80.000 and it reached to more than 120.000 by (GPC Gel Permeation Chromatography) and it was (21.5\%) of mastic gum (Sharifi, Hazell, 2009).

The produced gum from the male and female trees may be affected with trees ages, seasons, temperature, land topography, types of soil and locations, these 
factors affected the type of the produced gum of Acacia as far as tree and climate age and state of the soil and the seasonal difference (Lelon et al., 2013).

The gum produced from pistachios and terebinth grown in the north of Iraq which is called (water gum) is collected, and Mosul city is considered one of the model cities to grow pistachios which is known with its wide lands of pistachios cultivated in the surrounding areas (Al-Jowari, 2009).

\section{MATERIALS AND METHODS}

Pistachios trees were selected to be studied from one of the farms in Hawi AlKanessa region on the right bank of Tigris river in Mosul city, they were from Ashouri type, they were selected from the middle of the farm and not that from farms edges. They were free of insects or fungal infections.

Table (1) shows the studied trees diameters

Table (1): Trees Diameters (cm)

\begin{tabular}{|c|c|c|c|c|c|c|c|c|c|}
\hline \multicolumn{10}{|c|}{ Age (year) } \\
\hline Gender & \multicolumn{3}{|c|}{16} & \multicolumn{3}{c|}{23} & \multicolumn{3}{c|}{35} \\
\hline Male & 11.5 & 11.1 & 11.3 & 17.2 & 17.2 & 16.4 & 29.6 & 29.3 & 29.1 \\
\hline Female & 11.1 & 11.0 & 10.5 & 16.5 & 17.0 & 17.2 & 29.1 & 29.1 & 29.2 \\
\hline
\end{tabular}

Three wounds were made on the trunk of each tree with dimensions $(2 \times 1 \mathrm{~cm})$ and a height $60-80 \mathrm{~cm}$ on soil surface, the wound position and the surrounding area are cleaned from dusts then a plastic Can with holes $(2 \times 2 \mathrm{~cm})$ was put on the wound and connect strongly with a black substance to ensure the effect of the collected gum with sun.

Wounding operation started on $1 / 7 / 2013$ and the second wounding was on $1 / 8 / 2013$, the third wounding was on $1 / 9 / 2013$, then the gum for each four days was collected and the wound is cleaned each ten days, it has been shown that wounds produce gum abundantly through the first four days then starts to drop till the tenth day, so the wound has to be cleaned so as the tree can produce the gum but with low amounts, after a month the tree will stop producing the gum if the wound is not cleaned, where it healed and becomes bold brown or black.

Yield:

The process of collection (mastic gum) starts after four days of wounding and determining the weight with the can first then casting away the weight of the can when it is full from the empty one to obtain the weight of the substance after four days, then the weight of the can was determined again because the can will contain the adjacent gummy substance on the walls of the can, then we did that again each four days, after the first process ends, the weights were collected to obtain the total weight and they are put in the refrigerator and kept to make the rest of tests.

Essential oils:

Samples of gum ( 25 grams) were taken and put in rotary distillation device, the sample is distilled for four hours and the essential oils are taken from the receiver dish, 5 milligrams of Pentane is added to increase the volume, the solution is dried by adding 2 milligrams of anhydrous sodium sulphate, the solution is poured and filtrated to remove sodium sulphate and put in open dish all the night so 
as to vaporize Pentane, then the produced essential oils were weighted (Sharifi and Hazell, 2009).

Polymer: 25 grams of mastic gum were taken and dissolved in 25 milligrams of Diethyl ether and lightening it in 175 milligrams of methanol, the solution was left in closed flask for one night, then the solution was added to isolate the precipitate, then 20 milligrams of distilled water were added gradually, 1.5 grams of magnesium chloride were added. later, the solution was mixed for half an hour then it is left for overnight. White substance could be seen as a polymer substance (Sharifi and Hazell, 2009)

Statistical Analysis:

The experiment was conducted on pistachio trees in Hawi Al-Kanessa region / Mosul in a practical experiment of complete random design, with three factors; the first factor was represented with gender at two levels, the second was the three levels of three trees ages, while collection date was with three levels, by using three refineries, so we have had (54) experimental units for each feature, after collection data, we analyzed them statistically by using SAS.

Yield:

\section{RESULTS AND DISCUSSION}

Mastic gum is considered one of the non-wooden economical products of forests, since the production of (CGMGA The Chios Gum Growers Association, 2015) was raised from 83389 kilograms in 2003 to 125845 kilograms in 2015 with a value of 14234316 Euros for the year 2015.

The statistical analysis and difference table (2) of the effect of the studied factors on the mastic gum yield in the experiment showed the high significant effect (at the level 1\%) of trees age and the date of collection pistachio gum amount, while the effect was significant (at the possibility level 5\%) of the tree gender factor, the interaction effect of gender with the age was high significant on the yield while there is no interaction effect of gender with the date or the age with the date, while the triple interaction of gender, age, and collection time had a high significant effect on yield.

Duncan's test of the influence of the studied factors (table 3) showed the moral superiority of the male gender (23.06) on the female gender (19.34), which is consistent with the statement in the leaflet CGMGA (2015), as well as, the researches mention that the male production is higher than the female and this is in line with what he pointed out by (Isfendiyaroglu, 2003) and (Boztok and Cokuysal, 2010) that Pistacia lentiscus having the feature that the male trees produce gums more than the female ones, also the age 35 was more significant than the rest of ages (28.95) and this is in agree with the researches which refer to the increase of productivity with the age increase (Anemos, 2012) and (CGMGA, 2015).

The effect of the date represents the weather and environmental conditions on the product and therefore the second date (August) on the dates of July and September and this may mean increasing the productivity with the increase in the temperature of the atmosphere where the rate of the average for August (25.00). averages of the July and September were not significantly different. The researchers 
Table (2): ANOVA for Yield, Essential oil, and polymer

\begin{tabular}{|c|c|c|c|c|}
\hline Source of variance & D. f. & \multicolumn{3}{|c|}{ MSE } \\
\cline { 3 - 5 } & & Yield & Essential oils & Polymer \\
\hline Gender & 1 & $186.6^{*}$ & 0.5007 & $26.516^{*}$ \\
\hline Age & 2 & $824.5^{* *}$ & $9.3274 * *$ & $210.101 * *$ \\
\hline Collecting time & 2 & $246.3^{* * *}$ & $1.1051^{* *}$ & $28.787^{* *}$ \\
\hline Gender * Age & 2 & $330.1^{* *}$ & $0.7940^{*}$ & 1.573 \\
\hline Gender * Collecting time & 2 & 9.21 & $7.0785^{* *}$ & 5.493 \\
\hline Age * Collecting time & 4 & 75.42 & $2.6740^{* *}$ & $12.975^{*}$ \\
\hline $\begin{array}{c}\text { Gender * Age * Collecting } \\
\text { time }\end{array}$ & 4 & $159.2^{* * *}$ & $0.9051^{* *}$ & $11.166^{*}$ \\
\hline Experimental error & 36 & 34.0 & 0.1955 & 4.0138 \\
\hline
\end{tabular}

*significant effect at 0.05 level

** significant effect at 0.01 level

Lelon et al. (2013) and Ali et al. (2013) referred to the effect of gum yield with the climate conditions and collection season, where gum in Greece is collected in July, August and September (Anemos, 2012) while it is collected in Algeria in April, May and June (Mohamed and Ghalem, 2009). Concerning the interaction of gender and age, the male yield average of 35 years (35.71) was significant on the rest of interaction which is not differed significantly with each other, and this is agreed with Correria and Barradas (2000) in the male trees of the big age which is longer than the female trees with the same age which have big crown and a big area of leaves and this gives more productivity. In the triple interaction of the effect of gender, age and collection date shows significant superiority of male gender with 35 years and the date of August (44.14) on the rest of interaction and it was lower than gender yield coefficient with the age of 16 years for September (8.62).

Essential oils:

Researches proved the activity of essential oils of mastic gum and pistachio gum against many types of bacteria and infective diseases (Ghalem and Mohamed, 2009) and (Ghalem and Mohamed, 2010).

The statistical table (2) showed the high significant superiority of age, collection date, and there is not any significant effect of gender, also the mutual interaction of gender and collection date and age showed a high significant effect, while the mutual interaction of gender, age was significant at the possibility level $5 \%$. Also there is a high significant effect of triple interaction among gender, age and collection age.

Duncan's test of the studied factors (Table4) showed that the age at 16 years was significantly superior on the rest of ages and its value was $15.8 \%$ and showed that there are significant differences of gender, concerning the collection date, July and August were superior than September and their values were 15.2, 15.1, 14.7 respectively, in the triple interaction the male gender levels were superior at the age 16 years with the collection dates of July and September where they were 16.0 and 
16.49 respectively with the same female level with the age 16 years for all collection dates were they were 15.7, 15.6 and 16.4 respectively, the lowest rate of the female gender was the age 23 years with a collection date September (12.9), these results differ from the results obtained by the researchers (Sharifi and Hazell, 2009), where the essential oils rate extracted from mastic gum were appeared with a rate of 5.20\% (Sharifi and Hazell, 2011), and also about20\%in their study of $P$. atlantica, and this is agree with what is referred by the researchers (IM et al., 2017) and that the essential oils differ according to the production method, the type of tree and the growing conditions.

Table (3): Duncan Test for the effects of gender, age, and date of collection and their interactions on yield.

\begin{tabular}{|c|c|c|c|c|c|c|}
\hline \multirow[t]{2}{*}{ Gender } & \multirow{2}{*}{$\begin{array}{c}\text { Age } \\
\text { (years) }\end{array}$} & \multicolumn{3}{|c|}{ Collecting time } & \multirow{2}{*}{$\begin{array}{c}\text { Gender* } \\
\text { Age }\end{array}$} & \multirow[t]{2}{*}{ Gender } \\
\hline & & July & August & September & & \\
\hline \multirow[t]{3}{*}{ Male } & 16 & $18.8 \mathrm{def}$ & $18.2 \mathrm{def}$ & $12.36 \mathrm{f}$ & $16.49 \mathrm{~b}$ & \multirow[b]{3}{*}{$23.06 \mathrm{a}$} \\
\hline & 23 & $14.17 \mathrm{ef}$ & $17.95 \mathrm{def}$ & $18.82 \mathrm{cdef}$ & $16.98 \mathrm{~b}$ & \\
\hline & 35 & $33.47 b$ & $44.14 \mathrm{a}$ & $29.52 b c$ & $35.71 \mathrm{a}$ & \\
\hline \multirow{3}{*}{ Female } & 16 & $14.03 \mathrm{ef}$ & $17.95 \mathrm{def}$ & $8.62 \mathrm{f}$ & $16.47 \mathrm{~b}$ & \multirow[b]{3}{*}{$19.34 \mathrm{~b}$} \\
\hline & 23 & 105.4ef & $25.40 \mathrm{def}$ & $17.62 \mathrm{def}$ & $19.35 b$ & \\
\hline & 35 & $30.29 b$ & 17.62def & $18.75 \mathrm{cdef}$ & $22.20 \mathrm{~b}$ & \\
\hline \multicolumn{2}{|c|}{ Collecting time } & $20.98 b$ & $25.00 \mathrm{a}$ & $17.61 \mathrm{~b}$ & \multirow{3}{*}{\multicolumn{2}{|c|}{ Age }} \\
\hline \multirow{2}{*}{$\begin{array}{l}\text { Gender* } \\
\text { Collecting } \\
\text { time }\end{array}$} & Male & $22.18 \mathrm{ab}$ & $26.77 \mathrm{a}$ & $20.23 \mathrm{bc}$ & & \\
\hline & Female & $19.78 \mathrm{bc}$ & $23.24 \mathrm{ab}$ & $15.00 \mathrm{c}$ & & \\
\hline \multirow{3}{*}{$\begin{array}{c}\text { Age* } \\
\text { Collecting } \\
\text { time }\end{array}$} & 16 & 16.46def & $22.49 \mathrm{~cd}$ & $10.49 \mathrm{f}$ & \multicolumn{2}{|c|}{$16.48 \mathrm{~b}$} \\
\hline & 23 & 14.60 ef & $21.76 \mathrm{cde}$ & $18.22 \mathrm{cde}$ & \multicolumn{2}{|c|}{$18.16 \mathrm{~b}$} \\
\hline & 35 & $31.88 \mathrm{a}$ & $30.85 \mathrm{ab}$ & bc24.14 & \multicolumn{2}{|c|}{$28.95 \mathrm{a}$} \\
\hline
\end{tabular}

Means with different letters are significantly different at 0.05 level.

According to a personal interview with one of gum collector from the natural trees in Aqra region; the gum which is dried on the trees has a medical value higher than the gum which is manufactured as a dried in the markets, since it is produced after boiling the melting gum. Boiling process leads to make the gum lose their essential oils and then dropping their medical value of the gum. This fact was taken into consideration by analyzing the melting gum which is not dried to preserve the highest rate of the essential oils.

Researches refer that the oxide monoterpene form the greatest part of the essential oils components such as $\propto$-pinenewhich is considered the main component in the essential oils of gum extracted from mastic trees, pistachios and terebinth (Papageorgiouet al., 1991) and (Bozorgi and other, 2013) and its rate reaches to 97\% of essential oils in Batam gum (Sharifi and Hazell, 2011), also low rates of the components limonene, $\beta$-pinene, camphene and carracol. Essential oils have medical importance, where (Ghalem and Mohamed, 2009) proved that essential oils have antibacterial effect, since they showed an anti-activity for three types of bacteria: E.coil, Proteus and S. aureus. 
Table (4): Duncan Test for the effects of gender, age, and date of collection and their interactions on essential oils.

\begin{tabular}{|c|c|c|c|c|c|c|}
\hline \multirow[t]{2}{*}{ Gender } & \multirow{2}{*}{$\begin{array}{c}\text { Age } \\
\text { (Years) }\end{array}$} & \multicolumn{3}{|c|}{ Collecting time } & \multirow{2}{*}{$\begin{array}{c}\text { Gender* } \\
\text { Age }\end{array}$} & \multirow[t]{2}{*}{ Gender } \\
\hline & & July & August & September & & \\
\hline \multirow[t]{3}{*}{ Male } & 16 & $16.0 \mathrm{a}$ & $14.9 \mathrm{~b}-\mathrm{d}$ & $16.4 \mathrm{a}$ & $15.7 \mathrm{a}$ & \multirow[b]{3}{*}{$15.1 \mathrm{a}$} \\
\hline & 23 & $15.6 \mathrm{a}-\mathrm{c}$ & $3.57 \mathrm{de}$ & $14.8 \mathrm{~cd}$ & $14.8 \mathrm{~b}$ & \\
\hline & 35 & $15.6 \mathrm{a}-\mathrm{c}$ & $3.57 \mathrm{de}$ & $14.1 \mathrm{de}$ & $14.6 \mathrm{bc}$ & \\
\hline \multirow[t]{3}{*}{ Female } & 16 & $15.7 \mathrm{a}$ & $15.6 a-c$ & $16.4 \mathrm{a}$ & $15.9 \mathrm{a}$ & \multirow[b]{3}{*}{$14.9 \mathrm{a}$} \\
\hline & 23 & $14.1 \mathrm{de}$ & $15.6 a-c$ & $12.9 \mathrm{f}$ & $14.2 \mathrm{c}$ & \\
\hline & 35 & $14.1 \mathrm{de}$ & $16.0 \mathrm{a}$ & $13.7 \mathrm{e}$ & $14.6 \mathrm{bc}$ & \\
\hline \multicolumn{2}{|c|}{ Collecting time } & $15.2 \mathrm{a}$ & $15.1 \mathrm{a}$ & $14.7 \mathrm{~b}$ & \multirow{3}{*}{\multicolumn{2}{|c|}{ Age }} \\
\hline \multirow{2}{*}{$\begin{array}{l}\text { Gender* } \\
\text { Collecting time }\end{array}$} & Male & $15.7 \mathrm{a}$ & $14.5 \mathrm{c}$ & $15.1 \mathrm{~b}$ & & \\
\hline & Female & $14.7 \mathrm{c}$ & $15.7 \mathrm{a}$ & $14.4 \mathrm{c}$ & & \\
\hline \multirow{3}{*}{$\begin{array}{c}\text { Age* } \\
\text { Collecting time }\end{array}$} & 16 & $15.9 \mathrm{~b}$ & $15.3 \mathrm{c}$ & $16.4 \mathrm{a}$ & \multicolumn{2}{|c|}{$15.8 \mathrm{a}$} \\
\hline & 23 & $14.9 \mathrm{c}$ & $14.9 \mathrm{c}$ & $13.9 \mathrm{~d}$ & \multicolumn{2}{|c|}{$14.6 b$} \\
\hline & 35 & $14.9 \mathrm{c}$ & $15.1 \mathrm{c}$ & $13.9 \mathrm{~d}$ & \multicolumn{2}{|c|}{$14.5 b$} \\
\hline
\end{tabular}

Means with different letters are significantly different at 0.05 level.

Table (5): Duncan Test for the effects of gender, age, and date of collection and their interactions on polymer.

\begin{tabular}{|c|c|c|c|c|c|c|}
\hline \multirow[t]{2}{*}{ Gender } & \multirow{2}{*}{$\begin{array}{c}\text { Age } \\
\text { (Years) }\end{array}$} & \multicolumn{3}{|c|}{ Collecting time } & \multirow{2}{*}{$\begin{array}{c}\text { Gender* } \\
\text { Age }\end{array}$} & \multirow[t]{2}{*}{ Gender } \\
\hline & & July & August & September & & \\
\hline \multirow[t]{3}{*}{ Male } & 16 & $44.56 \mathrm{gh}$ & $45.5 \mathrm{fgh}$ & $47.26 \mathrm{efgh}$ & $45.78 \mathrm{~d}$ & \multirow{3}{*}{$49.47 \mathrm{a}$} \\
\hline & 23 & 48.40efgh & $51.16 a b c$ & $49.2 \mathrm{bcde}$ & $49.60 \mathrm{bc}$ & \\
\hline & 35 & $51.20 \mathrm{abc}$ & $54.86 a$ & $53.02 \mathrm{ab}$ & $53.03 \mathrm{a}$ & \\
\hline \multirow[t]{3}{*}{ Female } & 16 & $44.97 \mathrm{fgh}$ & $42.92 \mathrm{~h}$ & 45.90efgh & $48.65 \mathrm{c}$ & \multirow{3}{*}{$48.07 b$} \\
\hline & 23 & $43.96 \mathrm{gh}$ & 49.86bcd & $52.14 a b c$ & $48.65 \mathrm{c}$ & \\
\hline & 35 & $50.92 \mathrm{bcd}$ & $51.29 \mathrm{abc}$ & $50.66 \mathrm{bcd}$ & $50.96 b$ & \\
\hline \multicolumn{2}{|c|}{ Collecting time } & $47.33 \mathrm{~b}$ & $49.27 \mathrm{ab}$ & $49.71 \mathrm{a}$ & \multirow{3}{*}{\multicolumn{2}{|c|}{ Age }} \\
\hline \multirow{2}{*}{$\begin{array}{l}\text { Gender* } \\
\text { Collecting } \\
\text { time }\end{array}$} & Male & $48.05 b c$ & $50.51 \mathrm{a}$ & $49.85 \mathrm{ab}$ & & \\
\hline & Female & $46.61 \mathrm{c}$ & $48.02 \mathrm{bc}$ & $49.57 \mathrm{ab}$ & & \\
\hline \multirow{3}{*}{$\begin{array}{c}\text { Age* }^{*} \\
\text { Collecting } \\
\text { time }\end{array}$} & 16 & $44.76 b$ & $44.22 b$ & b $46.58 b$ & \multicolumn{2}{|c|}{$45.19 \mathrm{c}$} \\
\hline & 23 & $46.18 \mathrm{~b}$ & $50.51 \mathrm{a}$ & $50.70 \mathrm{a}$ & \multicolumn{2}{|c|}{$49.13 b$} \\
\hline & 35 & $51.06 a$ & $43.08 \mathrm{a}$ & $51.84 a$ & \multicolumn{2}{|c|}{$51.99 a$} \\
\hline
\end{tabular}

Means with different letters are significantly different at 0.05 level.

Polymer:

A study conducted by (Sharifi and Hazell, 2009) showed that a part of polymer of the gum has a high activity against the bacteria $H$. pylori and it was higher for the components which have the higher molecular weight (higher than 50000) where it was the double activity of the gum as a whole, table (2) of the difference analysis showed high significant effect for each age and collection date, while the gender has a significant effect at $5 \%$ and the significant effect of the mutual interaction between the age and collection date and also the triple interaction among the gender, age and collection date. 
Duncan's test (table 5) showed the superiority of the male gender on the female gender where polymer's rate was $(49.47 \%)$, the age 35 years was superior on the rest of ages in the polymer rate where it was $51.99 \%$, also the two dates of August and September were superior on July and the rate was 49.27 and $49.71 \%$ respectively. In the triple interaction, the male gender of the age 35 years and for all ages was superior on the rest of coefficients and it was less than the female genderat the age 16 years and for all collection dates. These rates differ from the polymer rate in mastic gum 21.5\% (Sharifi and Hazell, 2009) and this is due to the descriptions and the components of the gum are different according to the source and the climatic conditions, season and the age and types of trees (Ali and other, 2013).

تأثير الجنس والعمر وموعد الجمع في بعض مواصفات الصمغ المفرز من اشجار الفستق Pistacia vera $\mathbf{L}$.

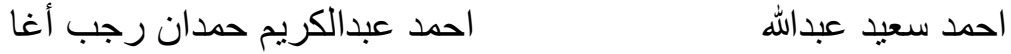

$$
\begin{aligned}
& \text { كلية الزر اعة و الغابات / جامعة الموصل }
\end{aligned}
$$

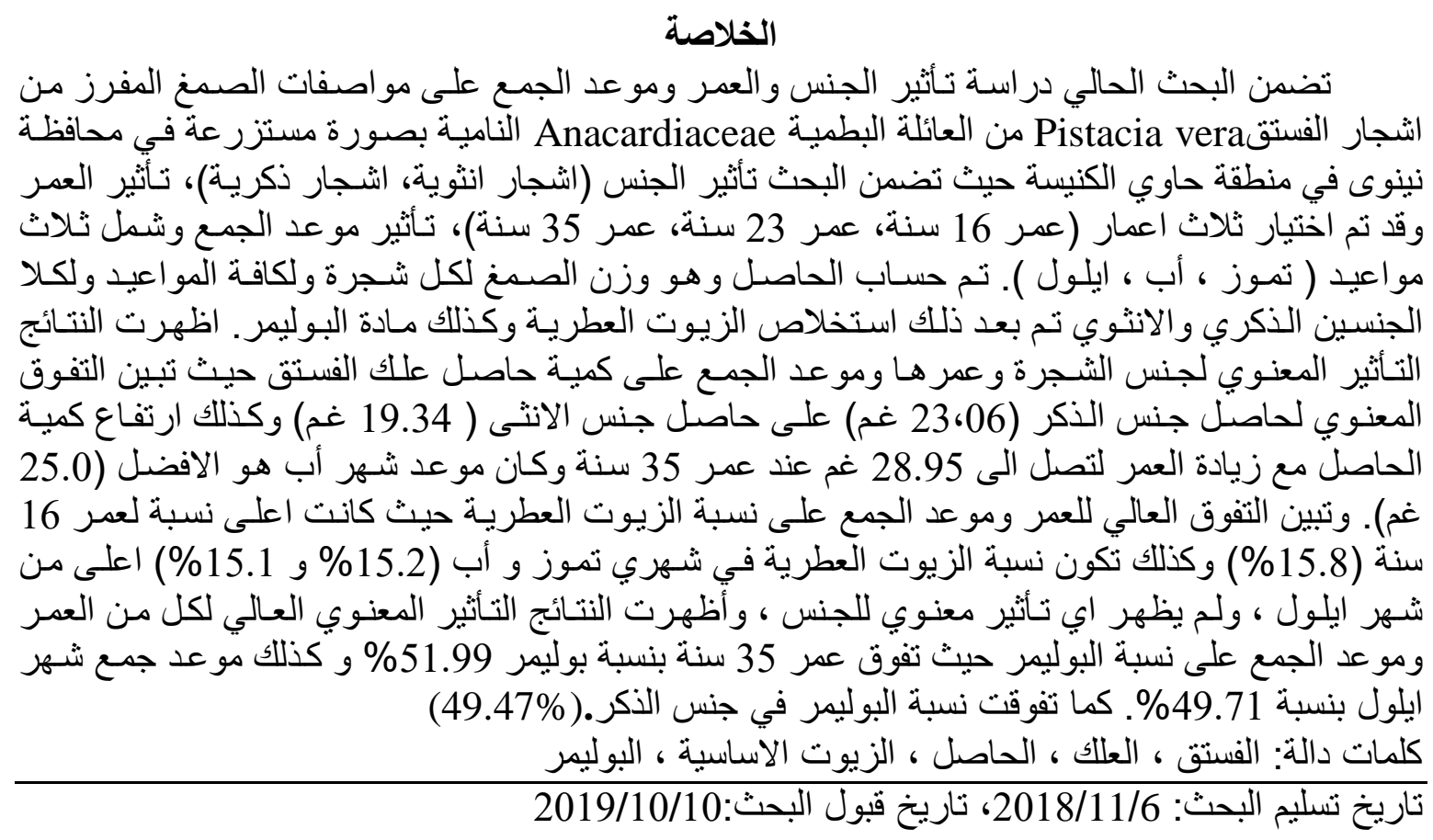

\section{REFERENCES}

ALI. B.H; S. Beegam; I. Allawati; M.I Waly; M. AlzaAbi. and A. Nemmar (2013) Comparative efficacy of three bands of gum acacia on adenine-induced chronic renal failure in rats, physiology Res. 62:47-56.

Al_ Jowary, Haees,(2009), Identification Comparative Study Of Morphology And Chemical Characteristics Of Pistacia Vera In Nineveh Governorate. Ph.D. Thesis, College of Agriculture and Forestry, University of Mosul. 
Al-Mofarji Talib; Nahidha R.AL-Zahid; Esra H. AL-hashimy. (2013) Antimicrobial effect of Mastic gum on aerobic oral bacteria .Iraqi National Journal of Nursing Specialties. Vol. 26 (2) : 136 - 140.

Al_Shahaat, Abu ZaidNaser, (1998), Aromatic Plants And Its Agricultural And Pharmaceutical Products. Aldar Alarabia For Printing And Distribution Cairo , Egypt. pp: 474 .

Anemos, (2012) Chois Mastic Gum Information. Anemos company .pp:1-13

Bailey, LH. (1963) How Plants Gets Their Names. Minola, NY, Dorer Puplication, Inc.

Balan ,K.V; J. Prince;Z. Han.; K Dimas; M. Cladaras; Z. Han; J. H.Wyche;P. Pantazis.(2007) Antiproliferative activity and induction of apoptosis in human colon cancer cells treated in vitro with constituents of a product derived from Pistacia Lentiscus L. var. chia. Phytomedicine. April 14 (4) : $263-72$.

Barton, D. H. and Seoane, E. (1956) The constitution and stereochemistry of masticadienonic acid. J.chem.Soc.801:4150-4158.

Bozorgi, Mahbubeh; Zahra Memariani; Masumehmobli; Mohammed Hossein Seleh Isurmaghi; Mohammed Reza Shams Ardekani; and Roja Rahim (2013).Five pistacia species (P.vere, P.atlantica, P.terebinthusP.khinjuk and P.Lentiscus): A review of their traditional uses phytochemistry, and pharmacology. The Scientific World journal vol.2013, Article ID $219815, p p: 33$.

Boztok, S. and U. Zeybek (2004) Investigation Of The Evaluation Of Some atural Plants Including Pistacia In Terms Of Gum Resins . Evaluation In Food And Drug Industry. Ege University Agricultural Application and Research center .IZMIR.

Boztok, Seol and Burcin Cokuysal.(2010). Ecologic Evaluation of Pistacia Lentiscus (MASTIC) in Cesme Peninsula ,Ege University, Agricultural Research Center. http://www. burcincokusal. blogspot. com/2010, 101/ ecologic-evaluation of Pistacia .html.

Correia. o and M.C Diaz Barradas (2000). Ecophysiological differences between male and female plants of Pistacia lentiscus. Plant Ecology , 149:131 142 .

Gallis. christos; Mariella Distefano; Paraskevi Moutsatsou; Tyhisarjala, Vesa Virtanen; Bjarne Holmbom; Joseph A. Buhagiab and Alexandros Katatunos (2011). Forest Products With Health - Promoting And Medicinal Properties. Forest, Trees and Human Health. Springer. pp:409.

Ghalem B. R. and B. Mohamed (2009). Essential oil from gum Pistacia atlantica Desf screening of antimicrobial activity, African journal of pharmacy and pharmacology . vol.3(3). pp:081-087.

Ghalem Bachir Raho , and Benali Mohamed (2010), Antimicrobial activity evaluation of the oleoresin oil of Pistacia vera L. African Journal of plant Science vol.4(8),pp:300-303. 
Ibnal al_Baytar(2001) Kitab al_Jami Li_Mufradat al_Adwiya wa _al _Aghdhiya (Arabic ). Scientific Books Home. Beirut. Lebanon. pp:174.

Im JJ: HS Jeong; YA Chung and IU Song (2017) Beneficial clinical effects of Chios Mastic Gum: A review. Austin Biology. Vol. 2(1):1022

Isfendiyaroglu Murat (2003). Effects of some physical and biochemical factors on the roting of mastic tree (pistacia lentiscus ver.chia duhan) cuttings. Ege Univ. Ziraat Fak. Derg. , 40(1):25-32 .

Lelon J.K;1.0 jomba; j. k. Keter and F.D.O Oduor (2013). Influence of Acacia Senegal varieties on quality of gum Arabic in Baringo District Kenya. African Journal of plant scince. Vol.7(6):190-200 .

Min Ji-Hak; Do kyunkim; Hyun-HoKwak; Gyoo-Cheon Kim; Seung-Eun Lee;InRyoung Kim; chul-Hoon Kim and Bong soo park(2009). Chios gum mastic induces cell cycle arrest and apoptosis in human osteosarcoma cells, The Korean j.Anat.42(4)245-256.

Monaco Pietro; R.Caputo; and G.Palumboil. Mangoni (1973). Triterpens from the galls of Pistacia lentiscus. phytochemistry. Volume 12(10): 2534 2537.

Papageoriou V. P.; Anntonios S. Mellidis; and Niki Argyridou. (1991). The chemical composition of the essential oil of mastic gum. Journal of essential oil research. 3(2): 107-110

Sharifi, M.S.(2006). Fractionation And Analysis Of Trunk Exudates From Pistacia Genus In Relation To Antimicrobial Activity. Ph.D. Thesis, College of Health and Science, University of western Sydney, Australia .

Sharifi , Mohammed Sharif and stuart loyd Hazell . (2009). Fractionation of Mastic Gum in Relation to Antimicrobial Activity. Pharmaceuticals, 2(1):2-10.

Sharifi, Mohammed Sharif and stuart Loyd Hazell (2011). GC-MC Analysis and antimicrobial activity of the essential oil of the trunk exudates from Pistacia atlantica Kurdica. Journal of pharmaceutical Science and Research. Vol. 3(8), 1364-1367.

Chios Gum Mastic Growers(2015).Basic Economic Figures. https://www. gummastic.gr /en/company/financial-data .

Van Den Berg K.; J.V.D. Horest; J.J Boon;Olof O. Sadeiijer (1998). Cis-1, 4-poly -B-myrcene; the structure of mastic resin (Pistacia lentiscusL.) elucidated . Tetrahedron letters. Vol. 39(17):2645-2648

Yousefi, Bayzid(2016), Influence of ecological variation across Pistacia atlantica on fruit oil content ,Folia Horticulture .28(2):117-124. 